\title{
Making persons in Sepik society: Suun and Kandimboang in Murik ritual and trade
}

Objets et fabrique de la personne: Suun et Kandimboang dans les rituels et les échanges du Murik

\section{Kathleen Barlow}

\section{(2) OpenEdition}

\section{Journals}

Electronic version

URL: http://journals.openedition.org/jso/8479

DOI: $10.4000 /$ jso.8479

ISSN: $1760-7256$

\section{Publisher}

Société des océanistes

\section{Printed version}

Date of publication: 15 July 2018

Number of pages: $15-24$

ISBN: 978-2-85430-135-9

ISSN: 0300-953x

\section{Electronic reference}

Kathleen Barlow, «Making persons in Sepik society: Suun and Kandimboang in Murik ritual and trade », Journal de la Société des Océanistes [Online], 146 | 2018, Online since 15 July 2020, connection on 23 July 2020. URL : http://journals.openedition.org/jso/8479; DOI : https://doi.org/10.4000/jso.8479 


\section{Making persons in Sepik society: Suun and kandimboang in Murik ritual and trade}

by

Kathleen BARLOW*

\begin{abstract}
The Murik, living in mangrove lakes at the mouth of the Sepik River, have long been noted for producing twill-plaited bags and wood carvings of human figures that are traded throughout the region and in contemporary times sold in markets and to tourists. Museum collections invariably contain examples of these two types of objects, testifying to their ubiquity but often lacking information about their cultural significance within the culture, in the regional exchange network or in the cash economy. Locally these two kinds of object play an important role in expressing and mediating claims to identity, status and group membership, and are deployed to mediate contradiction or avert conflict. I examine their relationship to personhood and leadership status in two rites of passage - initiation into leadership authority and end of mourning - and in local, regional and market arenas of exchange.
\end{abstract}

KEYwORDs: twill-plaited bags, carved figures, Murik, exchange, personhood

The circulation of objects, as complex expressions of persons and relationships is a longstanding fascination in Oceanic ethnography. From Mauss's initial insight that exchange of objects between groups builds social relationships, ethnographic discussions have moved through a range of analytic perspectives to current emphases on agency and process (see Bell and Geismar, 2009). Thomas (1991), Besnier (2011) and others (e.g., Bolton, 2003; Silverman, 2000, 2013) have enjoined Pacific ethnographers to explore the

\section{RÉSUMÉ}

Les Murik, qui vivent au bord de lacs bordés de mangrove près de l'embouchure du Sepik, sont depuis longtemps reconnus pour leur production de panier tressés et leur figures sculptés en bois vendus de nos jours sur les marchés locaux et aux touristes. De nombreuses collections de musée conservent des exemples de ces deux types d'objets, ce qui démontre leur omniprésence, mais les informations sur leur sens et sur leurs rôles dans les réseaux d'échange régionaux ou l'économie de marché sont lacunaires. Localement ces deux types d'objets jouent un rôle important dans l'expression et la revendication identitaire, le statut des personnes et leurs places dans la société mais servent aussi d'arbitre face à des contradictions ou afin d'éviter des conflits. Dans cet article jexamine leurs relations aux personnes et au pouvoir dans deux rites de passage - linitiation à une position d'autorité et la levée du deuil - et dans les échanges locaux, régionaux ou au sein d'un marché plus large.

Mots-ClÉs : sac de fibres tressées, figure humaine, réseaux d'échange, Murik, personne

consequences of colonialism and post-colonial modernity on modes of expression and meaning about persons, things and society. Current discussions emphasize the processes (technology) through which objects construct identity, relationships and value for individuals and groups (e.g. Coupaye, 2009; Leach, 2002), and consider the use of objects in rituals to effect changes in personal status and identity and relationships within and among groups (Bonnemère, 2004; Jeudy-Ballini and Juillerat, 2002). 
Two art forms from the Murik Lakes region at the mouth of the Sepik River in Papua New Guinea are frequently found in museum and private collections throughout the world and have made their way into the market for arts and crafts. Nevertheless, they continue to be important in contemporary life cycle rituals. The art forms are suun, twill plaited bags (in Murik language) (basket in Tok Pisin) and kandimboang, carved human figures (in Murik language). Both are familiar objects in everyday life and have spiritual, social, political and economic power in specific contexts. Although each could be analysed through its technical production process with respect to agency, constitution of kin group relationships and gendered personhood (e.g., Hermkens, 2013; Leach, 2002), here I consider their role in contemporary rituals that situate persons in relation to descent group membership, ancestral empowerment and personal identity (Bonnemère, 2004, 2017; Weiner, 1976, 1988). These objects remain prominent in rituals involving descent group membership and leadership status and in rituals of mourning and end of mourning. They communicate within and beyond Murik society about personhood, status and gender. Transacting these objects beyond Murik society in regional exchange or for sale involves re-working local expressions of personhood, status, and spiritual presence in terms of new political and economic contexts. The large repertoire of these two signature art forms may be imperiled as challenges grow to producing the ritual events in which they are most impactful, as commercialization diminishes their role in establishing contemporary personhood, and as the values they represent are increasingly mediated through market capitalism and displaced by Christianized belief systems (see also Hermkens, 2013, for Maisin tapa).

Living on narrow sandbanks between mangroves and ocean at the mouth of the Sepik River, Murik are fishers and traders whose leaders draw power from the ability to acquire resources and prestige from a far-flung trade network. Since the 1980 's, when I first did research among them ${ }^{1}$ they have been drawn ever more into the market economy. Resources formerly available through exchange now have to be purchased, as do education, health care, transportation and housing in town. As traders, Murik are expert at assessing and exploiting what other people want, and at flexibly adjusting the terms of transactions in different contexts, yet overall they favor an ethic of generous giving. With respect to suun and kandimboang, which locally express personhood and status in terms of kinship, Murik continue to adjust the terms under which local forms are shared in wider networks of status and prestige, while protecting their value within Murik society. As objects move through different kinds of economic transactions from gift-giving to market, they signify in different ways about the personal status of maker and receiver and the person to person relationships of those involved in their making and transacting. Under some conditions and in specific forms, each can be a kind of "inalienable possession" (Weiner, 1992); but otherwise as they circulate, they establish various kinds of relationships to non-Murik, such as kin, trade partner, ally, friend, and customer. Below I consider personhood and leadership as defined within kin relationships and describe the objects in terms of their relation to gender and person before turning to a discussion of their role in two life cycle rituals and how their significance shifts under conditions of social change.

\section{Personhood and status in Murik Society}

In Murik culture personhood is conceptualized as maternal presence, that is, prestige is gained from the nurture and generous deployment of resources on behalf of others, activities which Murik themselves identify with mothers, prominently characterized by feeding others (Barlow, 2010). Mothering/maternal action in Murik culture, is not passive and domestic, as it tends to be characterized in Euro-American society. In Murik culture it is assertive, resourceful, and gives power over others associated with the ability to prevent or quell antagonism and restore peace with prestations of good food (see von Poser, 2013, for a similar value on giving food, but not specifically conceptualized as maternal). Full personhood requires sharing resources in extended cycles of reciprocity as generous givers, especially of food. This nurturant form of authority enables men and women to be "big" based on generosity to others. Seniority overrides gender in determining who should be generous to whom, and thus men who share food and give feasts may be said to be "good mothers" to their subordinates. Gender difference is characterized by specific kinds of work: for men, house-building, canoe construction, regional trade, fishing with nets and in the open ocean, and carving; and for women, producing and preparing food, carrying water, gathering firewood, maintaining their household, fishing and gathering shellfish and weaving twill-plaited bags. Making bags is an essential part of Murik women's identity and all women learn to weave (including, eventually, me); but not all men become wood carvers (see Lipset, 2005). Sharing food and doing work enable a person to move from the dependent 
neediness of childhood to adult status as someone who is resourceful and can influence others by offering them what they desire.

Murik social organization is a form of exogamous ambilineal descent. Descent groups (poang in Murik language) are residentially dispersed across villages and ranked generationally and internally by sibling sets (nog in Murik language) according to a principle of primogeniture. An individual may claim membership in any descent group to which one of his/her four grandparents belongs and should marry someone who is not a descendant of their grandparents' siblings. Because each individual can claim affiliation in and be claimed by multiple descent groups, the groups compete for the loyalty (expressed through work and resources) of individuals. Leadership status depends on the ability to manage ritual and trade projects and bring them to fruition in an occasion of spectacular display. Life cycle rituals require bringing in resources from the larger region and hosting the assembled participants and audience for several days. Claims to status are evaluated in terms of success at sponsoring ritual events and feasts.

Senior siblings inherit resources, take responsibility for their distribution and use, and organize work on behalf of the larger group. Initiated senior siblings of each descent group are charged with ensuring that ritual work supported by regional exchange is accomplished. The resources they distribute include access to mangrove channels for shellfish, wood and plant fibers, and work projects include the building of men's and women's houses and large canoes, and magic spells. They are responsible for assembling suman (authority in Murik language) emblems, made primarily of boars' tusks and bird of paradise feathers, for public presentation. Suman represent the power and productive leadership of senior siblings, whose presence invokes peaceful and cooperative social relations. In addition to ritual action sponsored by a descent group, a suman gwan (son in Murik language) or suman merogo (woman in Murik language) assembles and carries suman to ensure safe passage through conflict. The physical presence of an initiated senior sibling (with or without the actual suman insignia) constitutes the presence of suman. Trespass against their authority by insult or aggression requires reparations in the form of pigs and feasts. Leadership is not completely symmetrical with respect to gender, as much decision-making occurs in the men's house, where $s u$ man merogo exercise influence indirectly through a younger male sibling. Also, women's power is exercised primarily through food as a means to quell antagonism, although a suman merogo also may walk into a fight and stop it by raising her hands. Men also engage in fighting and warfare (more so in earlier times), and voyaging for trade. ${ }^{2}$

Suman gwan and suman merogo have incipient status based on birth order within their sibling set, but rituals for accomplishments of first-borns acknowledge their potential leadership as they grow up (Barlow, 1995; Lipset, 1997). Eventually an individual must show considerable initiative to produce the ritual event and accompanying feasts to retire the existing leader and take his or her place. They are then responsible for the wellbeing and prosperity of the group and for maintaining its membership in competition with other descent groups by organizing work and ritual activity. This status hierarchy extends from living persons into the realm of spirits/ancestor spirits, who as "retired" leaders have an advisory role.

Suun and kandimboang are signifiers of personhood, including personal identity, birth order and gender, descent group status and leadership. They are essential elements in life cycle rituals, in particular, the two rituals described below which continue to be performed in the context of much social change. For each object there are differentiated types whose circulation within and beyond the borders of Murik society is regulated in terms of who creates them and who exchanges them with whom. I briefly describe the repertoire of each object in order to show subsequently their role in ritual and to consider the impacts of social change on their continued production and use.

\section{The objects}

Suun designs identify persons and groups. Bags filled with food, betel nut and other resources represent the maternal power of giving generously and controlling others appetites with abundant resources. When displayed at rituals marking life cycle transitions, spirit entities of the different descent groups are called to inhabit their respective suun. Kandimboang represent participants (living or dead) who are not physically present but would otherwise have an active role, such as sponsorship. Both bags and carved figures, when displayed at rites of passage, have the capacity to enable communication between spiritual and mundane worlds. Kandimboang represent spirits and humans, both male and female. To empower trade, groups of small figures associated with specific voyaging canoes, gai masok (canoe spirits in Murik language), are installed in a canoe when it is launched to carry it to its destination and

2. Warfare and trade are not completely off-limits to women, and by all accounts they come to the defense of male kin when needed and sometimes travel to other parts of the trade network where they are honored for their contributions of baskets and seafood products. The cessation of warfare under colonialism, as in other parts of Melanesia, has extinguished a realm of masculine activity that contributed strongly to gender differentiation. 


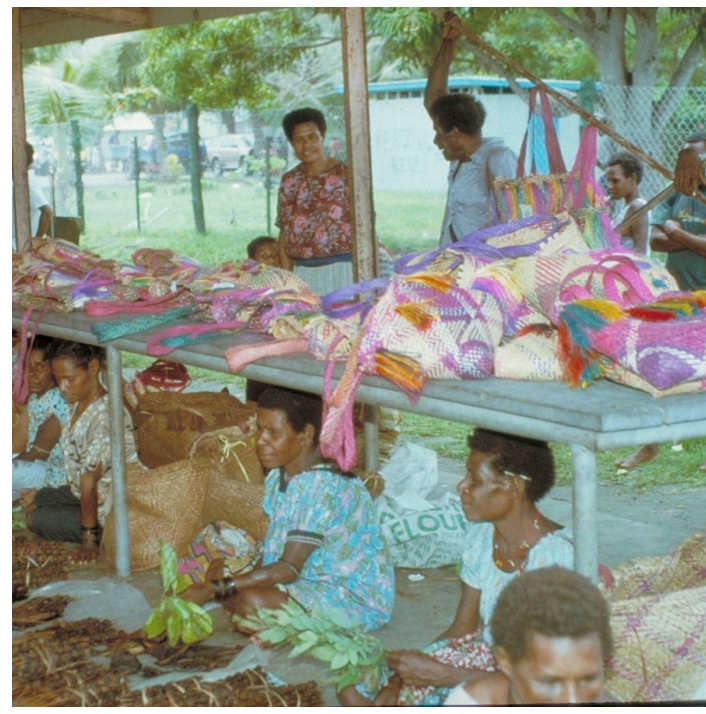

Рното 1. - Murik women and suun at Wewak market, 1982 (C) David Lipset)

back home again (Barlow and Lipset, 1997). Like suun, kandimboang are spoken of as gai'in (canoes in Murik language) for spiritual entities, and may be 'empty' vessels (inert objects) or spiritually empowered to legitimate activities and ensure their success, depending on context and purpose.

Suun belong in the growing discussion of Pacific women's textiles that create value by reproducing social persons through embodied practice (e.g., Bolton, 2003; Hermkens, 2013; Hermkens and Lepani, 2017; MacKenzie, 1991), although only limited consideration of their kinds, uses and signification is possible here. Each descent group owns a series of suun designs, but some designs are considered "public," meaning they can be made by all weavers and given or sold to anyone. Some of these make their way into the market, for sale to people from other groups in the region and to tourists (photo 1). A stronger and larger bag made for carrying garden produce, sabei suun (island bag in Murik language), circulates in regional exchange and is exchanged for desirable garden produce and pigs for ritual feasts. Recipients vie to claim these bags, and Murik women's reputations for quantity and quality of these relatively plain bags also figure in status at home (Barlow, 1985).

Individual persons are identified by the suun that they habitually carry. Someone in danger or recently deceased may be envisioned, "I saw him walking away down the beach. I saw his suun." Some designs are created for and belong to individuals, and thenceforth the design becomes their property. For example, a woman's son-in-law "saw" a design in a dream and described it to her. The third one she made met his expectations, and he carried it as his unique hallmark. A senior person who feels that death is imminent may ask a daughter to weave his or her final "basket," which must be done immediately. In other words, to carry a certain suun is to be a specific person; and the identity of object and person holds to such a degree that the suun, with all its signs of wear from use and handling, is considered to contain something of the spiritual presence of its owner. These suun also express the relationship between the maker and owner as mutually valued and supportive.

Descent-group-owned designs may be made and carried only by those who have earned the right to do so. Some are available to all members of the descent group, while others (referred to as suman suun) confer the authority of leadership status and the collective backing of the descent group's ancestors. The rights to suman suun are jealously guarded, and carrying one is a claim to leadership status not just within Murik society, but in the larger trade network. The danger of improperly transacting them is evident in the breach. In 1981 an effort to present a trade partner upriver with the gift of a suman suun was thwarted when it was pointed out that the giver had inherited the status but not performed the ritual retirement of his elder brother. None of his relatives was willing to deliver the suman suun under these conditions for fear of sorcery, and even though the maker's right to weave the design was not challenged, the controversial bag was destroyed (burned).

The repertoire of designs is maintained by women who are born or marry into a descent group. Weavers acquire designs through apprenticeship, invention, and practice. Individually-owned and descent group-owned designs have the most power to communicate personhood and status and are the most heavily guarded. In any case, if someone appears carrying a bag that a weaver considers illegitimate, she will slash it with a knife. An industrious woman produces bags of many sizes and types - for her own use, for family members, for exchange in the offshore islands trade network, for ritual occasions and to honor membership and leadership status. ${ }^{3}$ She is likely also to make bags to sell in the market, as do younger women learning to weave and experimenting with new design elements and techniques.

Kandimboang is a generic term for carved wooden figures in both male and female human form. They vary greatly in size from under 6 inches in height to standing figures 5-6' tall or more. The smaller ones may be gai masok, but larger ones are also used to invoke spiritual power from specific male and female spirits, mythic figures and ancestors in curing rituals in the men's house, and at initiations. Designs on the shoulders, back and stomach may indicate descent group affiliation and specific identity. Jari 
is an important female mythic figure in the region who came to the Murik Lakes from the West bearing outrigger canoe technology and gave knowledge of how to give birth to women (Lutkehaus, 1995; von Poser, 2014; Z'Graggen, 2011). These objects are kept in the women's (Tamoane, 1977) and men's houses - the former being a larger than usual dwelling house $\mathrm{e}^{4}$ - and deployed on certain occasions to call forth the spiritual presence and influence of the entities whom they represent. Because kandimboang require skill and conscious intention, and even spiritual inspiration to create, they are treated with respect and care. Figures with a long, hooked nose are spirit figures, while those with more human noses are meant to represent actual humans, or spirits in their human form. Nevertheless, apart from their deployment under certain circumstances (offerings made, words spoken to call forth presence and empowerment) the wooden figures are neutral material objects much of the time. On the other hand, to avoid unintentionally or negatively bringing forth their power, custodians of named figures keep them in special bags or bark containers in secluded places (such as the rafters or the back of the house). Their beneficent influence is dependent on treating them with respect, which includes refurbishing their ornamentation for proper display, and offering them food, tobacco and betel nut (photo 2). The figures are brought out on occasions when their support, as representatives of ancestral and contemporary spiritual presence, is important to the success of an undertaking.

For many years, small kandimboang of varying quality have been produced for sale to tourists and as gifts to visitors and others. Their prevalence in museum collections, early and more recently, suggests that they are both plentiful and perhaps not highly valued as individual pieces. As long as there are competent carvers, they can be replaced. Some are practice carvings, but well executed ones are cherished for their quality, which is assumed to result from spiritual empowerment of the carver's expertise. While carving, carvers abstain from food and sex to achieve absolute focus to carve well and without mistakes. Many people are able to identify a specific carver's "hand" or style of carving, and symmetrical, fully rounded forms with deeply and cleanly incised designs are signs of excellence. The shell, hair, and woven ornaments added to the wooden figures when they are presented or displayed locally often appear as part of the carved designs on kandimboang made for sale. Carvers do monitor quality and skill amongst each other and hope that excellence will also be noticed and appreciated by buyers.

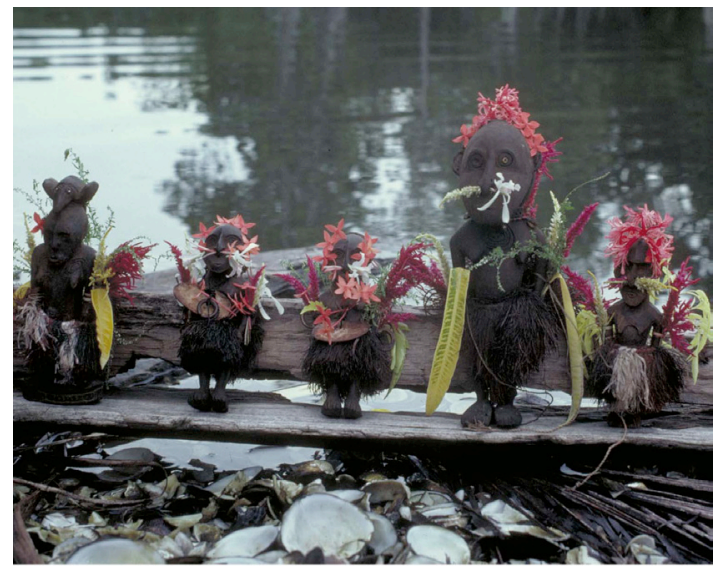

Рното 2. - Female kandimboang "dressed" for presentation, Darapap, 1981 (@ Kathleen Barlow)

In short, as objects circulate further afield from their role in producing local status and identity, designs become more generic/public signifying Murik identity rather than differentiated status. Those objects that can identify or mobilize spiritual or human presence are carefully guarded and unlikely to find their way into a market. When gifts confer intermediate statuses of membership and prestige on trade partners, they usually do not include the right to copy or transfer to others the design or object. Nevertheless, ever mindful that it can be useful and important to reach audiences beyond their borders, such as in Australia, Europe, or America, carvers and weavers do sometimes give and sell some of their signature objects as well. Locally significant objects may end up in museum collections, tourist art venues, and collections for two main reasons - a desire/need for money to cover health care, education, transportation, and other hard-to-come-by necessities; and a loss of commitment to local meanings based on church affiliations, educational change and urbanization. ${ }^{5}$ The durability of suun and kandimboang in their elaborated forms remains closely tied to Murik concepts of personhood and relational identity of ascribed and achieved descent group membership and status (Strathern, 1988).

\section{The rituals}

In today's world (1980's to present) much change has taken place that affects the expression of personhood, a primary function of the two objects considered here, and therefore a factor in their continuing to be made. The primary sources of change are citizenship in a democratic

4. Women's houses are situated within the village and occupied by a suman merogo, usually of a dominant descent group, and her family. Personal belongings are stored away when the house is the location of exclusively women's rituals, women's participation in larger rituals and their exchanges of plates of food.

5. The sale of some objects by those who adhere to "modern" beliefs and religion has become the subject of dispute and suspected cause of illness, misfortune or death within the kin group. 
nation-state, participation in a monetized, neoliberal economic regime, and the co-existence of indigenous religious beliefs and practices with many and varied forms of Christianity (see also Hermkens, 2013; Liep, 2007; Telban, 2008, for discussions of such change in other Melanesian societies). From the 1980's to the present, there have been increasing challenges to full performance of life cycle rituals that maintain cultural continuity with the past. Nevertheless, certain rituals expressing personhood that involve suun and kandimboang continue to be performed even when conditions prevent them from being fully realized: 1) initiation into suman holder status suman arekemara (meaning "to walk about with suman" in Murik language) or givim pen (meaning "to give pain/paint" in Tok Pisin) and 2) the end-of-mourning ceremony, called arobopera gar (washing celebration in Murik language), which brings a person who has been in mourning back to fully active social status. Despite changing definitions of personhood, these rituals affirm status within Murik society and identity throughout the region, and support on-going production of descent group affiliation and leadership status through specific material forms. They contribute to maintaining power relations and networks of relatedness based on local understandings about family, property and authority.

\section{"Suman arekemara"}

In earlier times, transitions in leadership status had mainly to do with firstborn status, and a younger sibling displaced the firstborn as he or she aged and became less active and effective at the ritual feasting and exchange required for good leadership. ${ }^{6}$ To initiate a new suman holder or to retire an aging one, requires many months of preparation, coordination of exchange activities throughout the region, manufacture of objects and decorations, food production that draws from exchange networks, and enough goods to host descent group leaders, dancers, and ritual sponsors from multiple villages for a number of days. In these ceremonies, the person undergoing the transition is visibly transformed to represent the new status and receives red body paint, body decorations, ornaments, loincloth or skirt or modern clothing, and suman. As an initiate parades through each village, he or she receives additional decorations that will be worn for subsequent ritual events and ceremonial occasions. The person's new status to sponsor feasts and exchanges is acknowledged with gifts of carved wooden plates and reeds for weaving suun (photo 3).

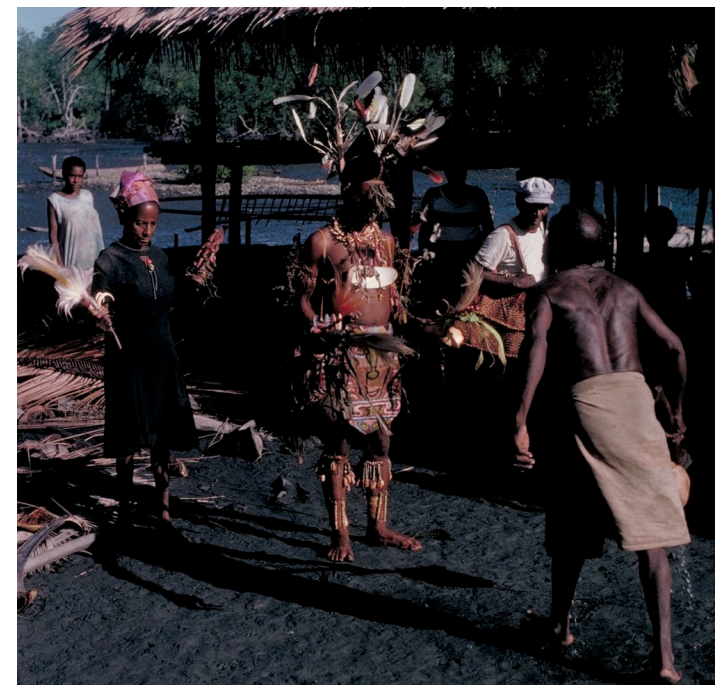

Рното 3. - A young male initiate walks through Karau village accompanied by ritual sponsors who carry suman, suman suun, and a kandimboang representing an absent older brother (C) David Lipset)

Once initiated, suman gwan and suman merogo are responsible for overseeing the legitimate use of descent group suman and other signature property, which includes named suun, kandimboang, named canoes, and other items either locally made or obtained through exchange, and constructed costumed figures. They decide whether outsiders may be given the privilege of carrying descent group related insignia. For example, in 1982, Kanjo, herself a suman merogo, conferred with her older brother for approval to weave a basket with a partial Yamdar suun design belonging to the Sait descent group as a gift to me. More recently, I encountered evidence that these bags continue to be given to trade partners and to identify relationships and privileges for the person who carries and uses them. In 2011, I attended a meal for the anthropologist, Nancy Lutkehaus, in the Manam Island settlement camp near Bogia. The senior man (tanepoa in Manam language) who sponsored the meal was carrying a suman suun received from his Murik trading partner and addressed me as Nancy's asimot (trade partner in Murik language) and therefore his. His well-used bag ratified his achieved status and relationships in a regional network.

Suman suun are carried and displayed for the transfer of leadership with all of its privileges and responsibilities. They invoke the power of earlier suman holders and even act as receptacles for their spirits. Helen Dennett, who photographed the canoe-shaped platform for the retirement of

6. Siblings are initiated in sequence by birth order, and when one parent decides to sponsor an initiation, others may join in. This co-sponsorship creates sets of initiates who may not be close in age, as this opportunity depends on their own parent's seniority and access to resources. For example, one set of women initiates ranged from married women with babies to pre-pubescent girls. 


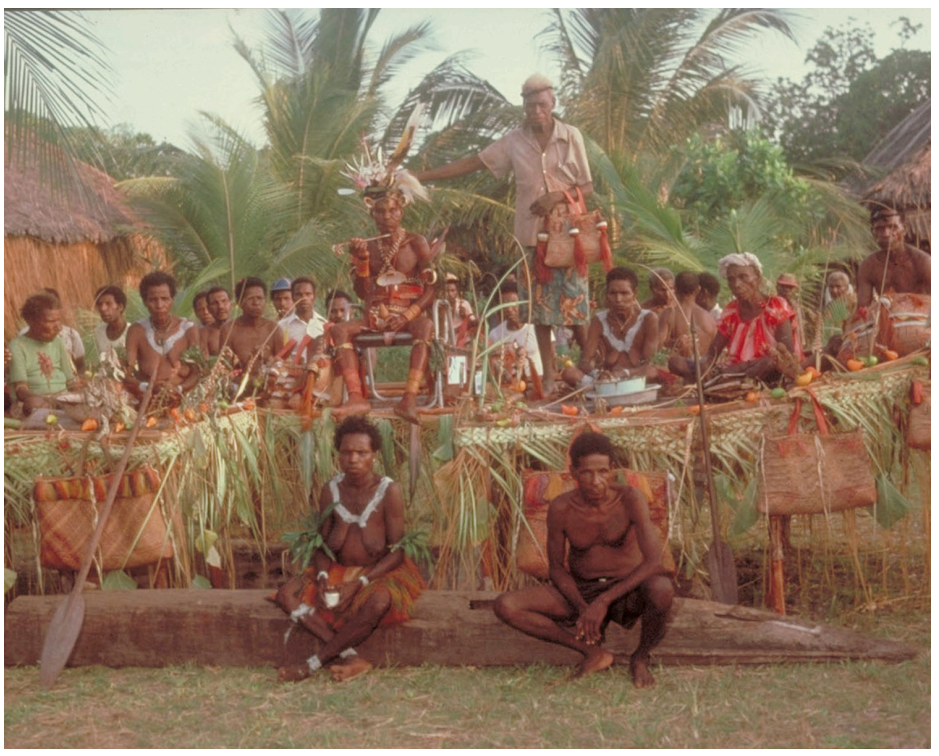

Рното 4. - Suman suun present at Sakara's retirement from suman gwan status, Big Murik, 1977 (C Helen Dennett)

Sakara in late 1970's, described an awe-filled hush that settled over onlookers as the suman suun were carried in to decorate the platform. These suun announce the authority and presence of ancestors who attend and witness the status (see also Revolon, 2007) (photo 4).

In contemporary times, important participants in these rituals are often absent because they live in town for work, education or health care, or are dispersed in distant towns and cities. Rather than postpone rituals indefinitely, they are performed without some of the required personnel. Kandimboang, selected by senior members of the appropriate descent group(s), represent absent persons. The figures themselves may be decorated as would be a person participating in the event.

By 2011 there seemed to be a trend toward creating larger groups of initiated siblings. Doing so increases the likelihood that there will be personnel present in the village to conduct needed rituals. The suman arekemara ceremony has an essential function in the making of Murik persons through descent group membership and in the organization of leadership functions. Suun and kandimboang are instrumental in these processes, even though current economic pressures and greater mobility require adjustments in personnel, frequency and scale.

\section{Arobopera gar - washing feast or celebration}

The end-of-mourning ceremony (arobopera gar) also continues to be essential, even though much of the reported ritual surrounding death is adumbrated or changed by Christianity. When a death occurs and again during the end-of-mourning ceremony both suun and kandimboang activate and contain the presence of spirits. The end-of-mourn- ing ceremony usually occurs about a year after a death and is performed by ritual sponsors (classificatory father's sisters or mother's brothers), who under normal circumstances are joking partners.

When a death occurs, the body is washed and decorated/clothed by mother's brothers for men or father's sisters for women. Mourners wail over the body throughout the day and following night. Ritual sponsors deploy themselves in full decoration to march around the body and insult the deceased, thereby determining the finality of death when no response is forthcoming (Barlow, 1992). Then suman holders of the deceased's descent groups present the appropriate suman insignia and hang their suman suun in the house near the corpse. They call out the deceased's names to the ancestor spirits, requesting that they receive this spirit back into their fold. But the spirit is expected to be frustrated, if not openly angry at the irreversibility of death, and to try to stay with loved ones among the living, and then to try to persuade those most beloved to go with it into the realm of the ancestors (see also Lemonnier, 2007, concerning ambivalence and danger associated with property of the recently deceased). The mourning period is in many ways a vigil to prevent this abduction. Many of the mourners' activities - covering their heads, remaining indoors, staying away from the beach at dawn and dusk - are ways to avoid being too visible and vulnerable to the spirit of the deceased. During mourning the closest relatives are said to "sit to the side" of social life and may not sponsor or participate in life cycle rituals, exchanges, celebrations or descent group-sponsored activities such as canoe building.

The arobopera gar ends the period of mourning by inviting ancestral spirits to come sing, dance and feast one last time with kin and then to be sent away more or less permanently to their abodes deep in the mangroves. As in the suman ceremony, if crucial living personnel (close kin or ritual sponsors) are absent, kandimboang may be presented instead. For this event, the deceased person's bag is hung in the center of the dance ground, and the spirit is called to reside there during the event (see also Revolon, 2007, on the presence of the dead through objects in Eastern Solomon Islands). An eerily beautiful song entices the spirits to come, and at dawn the next morning another very haunting song sends them away.

Suun with descent group or personally owned designs are poignant reminders of identity and loss, but also of continuity. During the arobopera gar, 
bags of the various descent groups to which the person belonged and of those in attendance hang inside the houses where men and women gather to sing throughout the night. At dawn the houses are swept from top to bottom and back to front to usher the spirits out into a special conical figure made of branches or through a waiting line of relatives with branches who escort and sweep the spirits and participants to the nearest body of water. There the spirit entities are dumped into the water - their medium of travel to return to their own abodes. The participants wash and come back onto land by jumping over a fire, often elements symbolic of (re-)birth (see Barlow and Lipset, 1997, for similar birth symbolism in launching a new outrigger canoe). Finally, those close kin who have been in mourning are shaved, given haircuts and new clothes, and presented a final mid-day feast. They are restored to full personhood, and may resume normal work and other activities, including re-marrying, participating in rituals, and taking up duties of leadership as appropriate. Suun and kandimboang are stored in their appropriate places in dwellings or men's houses until another occasion.

\section{Discussion}

Suun and kandimboang convey meanings across a broad spectrum of contexts, participants and activities, and signify in social, political, economic and religious dimensions. In ritual contexts within $\mathrm{Mu}-$ rik society, they enable status transitions, enforce the cultural status hierarchy, and monitor humanancestor connections and boundaries. Sunn bearing personal and descent-group-owned designs develop individual biographies and are valued for how they evoke the physical presence of certain people (Hoskins, 1998). When a personal carrying bag is burned following the close of an end-of-mourning ceremony (and it is done in a separate ceremony), the final link to the living person is destroyed (see also Venbrux, 2007). In local contexts suun and kandimboang mediate life transitions, and articulate changed social relations that radiate out from an individual or group's changes in status. Because of their power to confer status and authority, descent-group-owned suun designs are so closely guarded that a design can be extinguished if there is no one left who can make and carry it legitimately. With such complex meanings evoked by their presence and use, these objects move through regimes of value and meaning (Appadurai, 1988) and express and constitute the social relations in which they are embedded.
As mentioned above, bags deployed into the regional network are evaluated for quantity and quality, and the return in garden produce, pigs, or other needed goods is a response to this evaluation. (These exchange relations are more difficult to enact as more and more kinds of goods become commoditized.) If a woman who has sent bags on trade expeditions eventually visits the offshore islands, they decorate her and shower her with gifts. Deployed as gifts throughout the regional trade network, suun confirm on-going positive relationships and can be used to repair breaches. When a trade partner from one of the three villages to the east of the Murik Lakes (Kayan, Borbor, Marangis) died unexpectedly in the village of Big Murik, the Murik waited with trepidation to hear what compensation would be demanded. They feared the villages might send wave sorcery against them, but instead a very large suun (large enough to hold a pig) filled with other suun was requested to maintain good relations.

Suun that move beyond local cultural domains into exchange networks with non-Murik are given or sold to obligate others and to establish and maintain relationships. Their simplified, but colorful and eye-catching designs emphasize their economic and political dimensions. They are not specifically designed to convey statuses or to perform work in their new context, but to show beautiful craftsmanship as a signature of Murik women's skill. In this they compete with similar bags that are made by Chambri of the middle Sepik River and other nearby groups in the Lower Sepik. At this point in time, they also compete with commercial knock-offs sold in Chinese trade stores, but these imitations are considered so expensive and outside of Murik criteria of good workmanship, that women were quite dismissive of them or at least considered them irrelevant as competitors to what they make. Not so with the wildly flourishing bilum (netbag, Tok Pisin) of modern materials and design that have been adopted throughout Papua New Guinea (Garnier, 2009). Murik women carry them as personal items that show their participation in the modern economy and some women learn to make them. These bilum displace suun as women's bags for carrying personal items.

Kandimboang also undergo changes that disconnect them from personal and spiritual power as they are transacted into market contexts. In ritual contexts they temporarily may embody spirits, ancestors, and people who are called upon to witness or endorse a transition. Individual carvings that have specific identities do not serve as generic "canoes" for the spiritual presence of another. Because they are produced by men and circulate mainly

7. I am haunted by an image of a suman suun from the Australian Museum collection that in 1988 one woman in Wotam came to look at over and over and finally took the album of photographs back to an elder man in a distant house. When she returned, she shook her head sadly and told me, "All of the people who can make that basket have died." 
through the men's house, my knowledge of them is indirect, through myths and stories of objects given through trade connections as gifts or payment. There are accounts of kandimboang being given, stolen, and even "escaping" (as if under their own agency) into the possession of other owners within and beyond Murik society, and their powers are then at the behest of their new possessors or even entirely on their own, that is, out of bounds. In the (perhaps mythic) past battles have been fought to re-possess such objects (Lipset, 1997).

Kandimboang made for sale are usually small (under 12" tall), undecorated, but well carved. They may also be artificially aged, with black shoe polish, and smoke and cobweb debris from being stored above the hearth. Like bags made for a public audience they are distinctively Murik, but lack the features that would make them actively powerful in a ritual context (Lipset, 2005). They communicate contact with Murik people and perhaps carry Murik identity to a wider audience.

In contemporary society, Murik are often displaced to squatter settlements in towns for wagepaying jobs, and as suun and kandimboang are made more often for sale than for local use in rituals of transition and status, their meanings become more attenuated and shift to market based relationships, short-term and commoditized. In other words, the effects of growing participation in the cash economy are transforming local meaning into "craft" production for a modern market (see also Hermkens, 2013). On the other hand, the production and sale of suun and kandimboang has yet to be rationalized in terms of the labor it takes to produce them. Shorn of their local value in terms of the status and relationships they convey, they are sold into oblivion for prices based on what buyers are willing to pay.

These two material forms are signature elements of Murik identity, and for now, continue to be supported by the existence of skilled men and women to produce them, the ongoing organization of social, political and economic life through descent groups, and the crucial role of suman holder status and the emblems that ratify it. In regional networks, suun and kandimboang are endangered by commodification and by the instability of regional trade partnerships that occur with the monetization of the informal exchange economy. Appadurai (2006) points to the instability of persons and things as discrete categories, and notes the fluidity of the status of "things" as gift, commodity, art, junk, or heirloom. In the ongoing flow of personhood and things involving suun and kandimboang, one may hope that producers, users and consumers continue to participate in their circulation and that Murik actors continue to maintain the full repertoire of meanings and values the objects currently have the capacity to convey.

\section{REFERENCES}

Appadurai Arjun, 1988. The social life of things: commodities in cultural perspective. Cambridge, Cambridge University Press.

Appadurai Arjun, 2006. The Thing Itself, Public Culture 18 (1), Duke University Press, pp. 15-21.

Barlow Kathleen, 1985. The Role of Women in Intertribal Trade among the Murik of Papua New Guinea, Research in Economic Anthropology (7), pp. 95-122.

—, 1992. 'Dance When I Die!': Context and Role in the Clowning of Murik Women, in W. E. Mitchell (ed.), Clowning as Critical Practice: Performance Humor in the South Pacific, Pittsburgh, Univ. of Pittsburgh Press, ASAO Monograph Series, pp. 58-87.

-, 1995. Achieving Womanhood and the Achievements of Women in Murik Society: Puberty Rites, Cult Initiation and the Cultural Construction of Gender, in N. C. Lutkehaus and P. B. Roscoe (eds), Gender Rituals: "Female Initiation" in Melanesia, New York, Routledge, pp. 85-113.

—, 2010. Sharing Food, Sharing Values: Mothering and Empathy in Murik Society, Ethos 38 (4), pp. 339-353.

Barlow Kathleen and David M. Lipset, 1997. Dialogics of Material Culture: Male and Female in Murik Outrigger Canoes, American Ethnologist 24 (1), pp. 4-36.

Bell Joshua A. and Haidy Geismar, 2009. Materialising Oceania: New ethnographies of things in Melanesia and Polynesia, The Australian Journal of Anthropology 20, pp. 3-27.

Besnier Niko, 2011. On the Edge of the Global: Modern Anxieties in a Pacific Island Nation, Stanford, Stanford University Press.

Bolton Lissant, 2003. Unfolding the Moon: enacting women's kastom in Vanuatu, Honolulu, University of Hawai'i Press.

Bonnemère Pascale (ed.), 2004. Women as Unseen Characters: Male Ritual in Papua New Guinea, Philadelphia, University of Pennsylvania Press.

—, 2017. The Materiality of Relational Transformations: Propositions for Renewed Analyses of Life-Cycle Rituals in Melanesia and Australia, Anthropological Forum 27 (1), pp. 3-17.

Coupaye Ludovic, 2009. 'What's the matter with technology?' Long (and short) yams, materialization and technology in Nyamikum village, 
Maprik district, Papua New Guinea, Australian Journal of Anthropology 20, pp. 93-111.

Garnier Nicolas (ed.), 2009. Twisting Knowledge and Emotions: Modern bilums of Papua New Guinea, Boroko, Tropic Print.

Hermkens Anna-Karina, 2013. Engendering Objects: Dynamics of Barkcloth and Gender Among the Maisin of Papua New Guinea, Leiden, Sidestone Press.

Hermkens Anna-Karina and Katherine LepANI (eds), 2017. Sinuous Objects: Revaluing Women's Wealth in the Contemporary Pacific, Acton, Australia National University Press.

Hoskins Janet, 1998. Biographical Objects: how things tell the stories of people's lives, New York, Routledge.

Jeudy-Baldini Monique and Bernard Juillerat (eds), 2002. People and Things: Social Mediations in Oceania, Durham, Carolina Academic Press.

Leach James, 2002. Drum and Voice: Aesthetics and Social Process on the Rai coast of Papua New Guinea, Journal of the Royal Anthropological Institute 8, pp. 713-734.

Lemonnier Pierre, 2007. Objets d'ambiguïté : Funérailles ankave (Papouasie Nouvelle-Guinée, Journal de la Société des Océanistes 124 (1), pp. 33-43 (http://journals.openedition. org/jso/735).

LiEP John, 2007. Massim mortuary rituals revisited, Journal de la Société des Océanistes 124 (1), pp. 97-103 (http://journals.openedition.org/jso/).

Lipset David M., 1997. Mangrove Man: Dialogics of culture in the Sepik estuary, Cambridge, Cambridge University Press.

-, 2005. Dead Canoes: The Fate of Agency in Twentieth Century Murik Art, Social Analysis 49 (1), pp. 109-140.

Lutkehaus Nancy K., 1995. Zaria's Fire: Engendered Moments in Manam Ethnography, Durham, Carolina Academic Press.

Mackenzie Maureen Anne, 1991. Androgynous Object: String bags and gender in central New Guinea, Melbourne, Harwood Academic Publishers.

Poser Alexis von, 2014. The Accounts of Jong: A Discussion of Time, Space, and Person in
Kayan, Papua New Guinea, Heidelberg, Universitätsverlag Winter.

Poser Anita von, 2013. Foodways and Empathy: Relatedness in a Ramu River Society, Papua New Guinea, New York, Berghahn Books.

Revolon Sandra, 2007. The dead are looking at us: Place and role of the apira ni farunga ("ceremonial bowls") in end-of-mourning ceremonies in Aorigi (Eastern Solomon islands), Journal de la Société des Océanistes 124 (1), pp. 59-66 (http://journals.openedition.org/jso/).

Silverman Eric K., 2000. Tourism in the Sepik River of Papua New Guinea: Favoring the Local over the Global, Pacific Tourism Review 4 (2-3), pp. 105-119.

-, 2013. After Cannibal Tours: Cargoism and Marginality in a Post-touristic Sepik River Society, The Contemporary Pacific 21 (2), pp. 221-257.

Strathern Marilyn, 1988. The Gender of the Gift, Berkeley, University of California Press.

Tamoane Matthew, 1977. Kamoai of Darapap and the legend of Jari, in G. Trompf (ed.), Prophets of Melanesia, Port Moresby, Institute of Papua New Guinea Studies, pp. 174-211.

Telban Borut, 2008. The Poetics of the Crocodile: Changing Cultural Perspectives in Ambonwari, Oceania 78 (2), pp. 217-235.

Thomas Nicholas, 1991. Entangled Objects: Exchange, Material Culture and Colonialism in the Pacific, Cambridge, Harvard University Press.

Venbrux Eric, 2007. Robert Hertz's seminal essay and mortuary rites in the Pacific region, Journal de la Sociétè des Océanistes 124 (1), pp. 5-10 (http://journals.openedition.org/jso/712).

Weiner Annette B., 1976. Women of Value, Men of Renown: new perspectives in Trobriand exchange, Austin, University of Texas Press.

-, 1988. The Trobrianders of Papua New Guinea. Fort Worth, Harcourt Brace.

-, 1992. Inalienable Possessions: The paradox of keeping while giving, Berkeley, University of California Press.

Z'Graggen John A., 2011. The Lady Daria and Mister Kamandonga. A Legend of Papua New Guinea, Adelaide, Crawford House Publishing. 